\title{
The Choice of Language for African Creative Writers
}

\author{
Edadi Ilem Ukam ${ }^{1}$ \\ ${ }^{1}$ Department of English and Literary Studies, Veritas University, Abuja, (The Catholic University of Nigeria), \\ Nigeria \\ Correspondence: Edadi Ilem Ukam, Department of English and Literary Studies, Veritas University, Abuja, (The \\ Catholic University of Nigeria), Nigeria
}

Received: April 21, 2018

Accepted: June 16, 2018

Online Published: June 18, 2018

doi:10.5430/elr.v7n2p46

URL: https://doi.org/10.5430/elr.v7n2p46

\begin{abstract}
Language issue has been considered as a major problem to Africa. The continent has so many distinct languages as well as distinct ethnic groups. It is the introduction of the colonial languages that enable Africans to communicate with each other intelligibly: otherwise, Africa has no one central language. Among the colonial languages are English, French, Arabic and Portuguese which today serve as lingua franca in the mix of multiple African languages. Based on that, there is a serious argument among African critics about which language(s) would be authentic in writing African literature: colonial languages which serve as lingua franca, or the native indigenous languages. While some postcolonial African creative writers like Ngugi have argued for the authenticity and a return in writing in indigenous African languages, avoiding imperialism and subjugation of the colonisers, others like Achebe are in the opinion that the issue of language should not be the main reason in defining African literature: any language can be adopted to portray the lifestyles and peculiarities of Africans. The paper is therefore, designed to address the language debate among African creative writers. It concludes that although it is authentic to write in one's native language so as to meet the target audience, yet many Africans receive their higher education in one of the colonial and/or European languages; and as such, majority do not know how to write in their native languages. Rather, they write in the imposed colonial languages in order to meet a wider audience. Not until one or two major African languages are standardised, taught in schools, acquired by more than 80 per cent of Africans and used as common languages, the colonial languages would forever continue to have a greater influence in writing African literature. The paper recommendes that Africans should have one or two major African languages standardised, serving as common languages; also African literature should be written in both colonial and African languages in order to avoid the language debate by creative African writers.
\end{abstract}

Keywords: African writers, indigenous languages, colonial languages, Africanised English, Achebe, Ngugi

\section{Introduction}

There is no doubt that language and literature have both been considered as significant attitude of national identity and distinctiveness (Menang, 2001). A literature of every nationality serves to definethe language of that particular society. It can never be argued that today African literature has widely been written among the colonial languages of Europe and Arab, particularly English, French, Arabic and Portuguese, although with some African oral traditions, therebydisregarding many indigenous African languages. And many African writers have chosen to write and/or express their opinions by adopting most of the colonial languages, whereas other creative writers argue that African experience, belief and identity should only be better expressed by indigenous African languages, irrespective of the language barrier found in Africa. For instance, Ngugi wa Thiong'o, a Kenyan prolific writer, and many others such as Obiajunwa Wali as well as Abiola Irele, to mention a few, have all continued to argue that a literature created and documented in languages other than African languages is not qualified to be regarded as an African literature.

If language is defined as a system of arbitrary vocal symbols by means of which the members of a society interact in terms of their total cultures (Eme \& Mbagwu, 2011, p. 115), there is need to believe that the people's language is the best and authentic means through which the intended message is passed across. Eme and Mbagwu have considered two main factors through which the literature of the people could be expressed: first, the literature of the people should try as much as possible to address their language; and second, it should address the human society that speaks the language in particular. According the source, a language is the medium of expressionof the people and the human society is the provider of beliefs and manners in the society which are expressed by writers. If that is true, their 
observation shows that it is the people's language in particular that would determine or define their literature such as English literature, Portuguese literature, French literature, Arabic literature, German literature, Igbo literature, Yoruba literature and Erei literature, among many other world literatures.

In other words, for the fact that the people's literature cannot be discussed outside the context of their language, Mokaya (n.d., p. 1), has argued that the issue of language is the central figure of African literature, explaining that in order to define African literature accurately, the language of the people must first be considered. To him, despite the fact that language is the central issue to any literature, there hasbeen, for a number of years, a serious debate about the particular language(s) used in conveying African literature. The debate has truly brought demarcation and serious argument between two great and well-known African elites: Chinua Achebe and Ngugi wa Thiong'o.

The language controversy has led one to think of the ways through which African identity can be expressed linguistically: through indigenous African languages or through adoption of colonial languages. If therefore, we consider it reasonably that one cannot put together or sometimes one cannot overlap the uses to which both African native and adopted European languages could be put together on a daily basis in addressing African literature, then it seems practical that a literature that is both a factor and product of people's identity should take advantage in expressing and reflecting the complementary relationship that exists within the native languages in question. But would such assertion be possible in an African environment which has no single central native language?

For centuries, the people of Africa have handed down from one generation to the next a tradition of oral (folk) literature in their various native languages. And more recently, a tradition of literature produced in adopted foreign languages has developed alongside the African oral tradition (Ukam, 2008). The two traditions, that is, literature written in African native languages and literature written in colonial languages, constitute what is generally referred today as African literature. In the words of Manang (2001), it is the two traditions that "today's African nations are striving to build and consolidate their respective identities" (n. p). However, the questions that are yet to be resolved among African creative writers, critics, linguists andevery person in African continent are: which of the languages should African creative writers produce their literature (Menang,2001), and is literature written in foreign languages not be considered as African literature?

It is the same questions that this present paper is about to answer with particular attention to the arguments (agreement and disagreement) between Chinua Achebe and Ngugi wa Thiong'o in particular, who have both independently expressed different conflicting opinions ever since some African writers met at Makerere University Kampala, Uganda in 1962. The paper shall, however, examine different arguments in this debate and then present a personal standpoint.

\section{The Arguments}

The debate concerning which language(s) African writers should use in addressing their literary works has brought in two arguments, although a carefully examination shows that both are not logically far from each other.The first argument is the one presented by Ngugi wa Thiong'o and his followers, who suggest that for a literature to be called "African literature" should, no doubt, be written in indigenous African languages. They oppose the fact that foreign languages (like English, French, Arabic and Portuguese, among many others) should not be acceptable languages used in portraying African lifestyles and perculiarities. The second group is led by Chinua Achebe and his followers who are mainly in favour of adopted foreign languages. To them, the colonial languages provide the possible solution in addressing African literature since, on one hand, there are so many diverse ethnic languages in Africa, and on the other, they can cover a larger range of population than the undeveloped African languages.

\section{Ngugi wa Thiong'o and Other Writers for African Languages}

There is no doubt that Ngugi wa Thiong'o is the most front runner of this group. Other writers and critics are Abiola lrele, Charles Nnolim, Obiajunwa Wali, Gabriel Ruhumbika and Mazisi Kunene, among many others. As we illustrated earlier, their major argument is that for African literature to be authentic and worth the name "African literature", it must be written in one of the African languages (Menang, 2001). They suggest that there is need to make one or two African languages official, and from which it would be used in writing a literature meant for African people.

Should African literature be written in African languages? Or should it be written about the people of Africans in a language other than their own? These are two pertinent questions that Ngugi wa Thiong'o tries to address. He suggests that African languages should be the only medium through which African writers can address the ways of life of their follow Africans; the languages provide direct access to the rich traditions of Africa and its people. To him, writing in one's native language (L1) is for identification and a way of fighting against the imperialist powers 
that can defend their cultural and national heritage. African languages are the sources through which African writers can struggle against wider imperialist domination by the colonisers. In 1986, Ngugi has suggested that African writers should always write in their L1, avoiding the old imposed colonial languages of English, French,Arabic and Portuguese, among others. According to him, although his earlier works (novels and plays) have been heavily written in English, yet he has switched to writing mostly in Gikuyu, a Kenyan language, in order to reach his target audience. He claims that decolonisation is possible only by liberating oneself from the power of the imperialist languages; it is the only way of reclaiming the cultural identity of a nation: "Language carries culture, and culture carries, particularly through orature and literature, the entire body of values by which we come to perceive ourselves and our place in the world" (Ngugi, 1972, p. 290). According to the source, the bullet used by the colonisers is a means of physical subjugation, whereas the used of the imposed colonial languages in depicting African literature is another means of spiritual subjugation.

In order to communicate to wider audience if there is need for it, Ngugi suggests that translation is possible since it ought to be the equalitarian mode of interaction between and among languages, and writing in his L1 would pass his message well to his common people. Also, it would show that he is no longer subjected to any colonial subjugation. $\mathrm{He}$ argues that writing in European languages is only for the educated elite class; and as such, literature written in any language other than African languages is not quality to be recognised as African literature. Rather, such literature should be considered as Afro-European literature.That is, the writers have created another hybrid tradition, a minority tradition that can only be termed as Afro-European (literature written by Africans in European languages), reaching only a limited audience, not a wider one (Ngugi, 1990).

Ngugi (1990) celebrates the merits of African national languages, arguing that he would like to see African writers writing in such a literature that would reflect the real rhythms of African child's spoken expression. He actually places African languages at the top of a hierarchy of languages used in depicting literature for the African writers. Apart from the communicating function of a language, Ngugi argues that writing in one's L1would help to express and carry the cultural heritage of the people, becoming a storehouse of its images, wisdom, experience and history. In his words, language is power: it draws the writer closer to his people. In other words, Ngugi is of the opinion that Europeans force their languages on Africa, and meanwhile, African writers have blindly accepted the offer, enriching another culture (European culture) with their own experience, thereby ignorantly disregarding theirs. He beleives that writing in any of the European languages by some African writers is another means of spiritual subjugation. He therfore, encourages African writers to be proactive and take a responsibility onto themselves to counter such imperialism. And he delves intowriting in his L1 (Gikuyu) because it is the only way to move away from European domination: "I believe that my writing in Gikuyu language, a Kenya language, an African language, is a part and parcel of the anti-imperialist struggles of Kenyan and African people" (Ngugi, 1986, p. 28). Ngugi challenges such African writers writing in European or imposed colonial languages to abandon such act.

In 1962 when African writers met at Makerere University Kampala, Uganda for a conference, with a topic entitled: A conference of African writers of English expression, Ngugi (1986), in responding to the meeting, particularly is not satisfied with the title itself, arguing that it does not collaborate with the conference and that it only defines African literature produced in English:

Was it literature about African or the African experience? Was it literature written by African? What about a non-African who wrote about Africa: did his work qualify as African literature? What if an African set his work in Greenland: did it qualify as African literature? Or were African languages the criteria? OK: what about Arabic, was it not foreign to African? What about French and English, which had become African languages? What if an European (sic) wrote about Europe in African language...? (p. 6)

To him, the conference excludes other African writers who wrote in African languages: it has failed to arrive at a generally agreed definition of African literature. He points out that most parts of the world today are writing in their L1: as such Africa should not be an exception. He warns that if African writers continue to write in European languages, it shows how they have been depressed by Europeans and Americans even after colonisation. Ngugi provides three reasons why heis encouraged to write in one of the African languages: first, writing in L1 allows the writer to share the same culture and ideology with his people through the eyes of others. Second, the writer would not be cut off from his people: he would help them to overcome the neocolonisation of Europe and be free. And thirdly, the people would also not be cut off from the writer (Ngugi, 1986). He concludes that writers like Achebe, who are mainly writing in European languages, are merely reaching the middle-class, not the entire masses. 
In addition to Ngugi's opinion of fighting for the adoption of African languages, Wali, in 1963, a year after the conference, suggests that for any literature to be called "African literature", it must be written in one of the African languages. He challenges African writers who primarily write in the imposed western languages: "...until these writers and their western midwives accept the fact that any true African literature must be written in African languages, they should be merely pursuing a dead end, which can only lead to sterility, uncreativity and frustration" (p. 97). Stating that he is not in total condemnation of those who write in imposed western languages, Wali emphasises that he is not in support with such practice. To him, African languages should not be underrated and/or depressed even by fellow Africans; rather, they should be widely promoted; and the only way to achieve such objectives is to write in indigenous native languages.

In Wali's view, literature should be able to promote the discourse of the people's language by imaginative literature. And that for any African writer who does not promote the indigenous languages is by and large killing the African literature. He concludes that if there should be originality and authenticity in African literature, it is only the literature written in any of the indigenous African languages could be fully classified as African literature. And that not until any true African literature is written in African languages, they would be merely pursuing a dead end.

In his reaction to the conference, Wali (1963) emphasises that the conference fails to come up with any authentic identifiable definition of African literature: "Perhaps the most important achievement of the Conference of African Writers of English Expression held in Makerere College, Kampala, in June I962 is that African literature as now defined and understood leads nowhere" (p. 330). To quote Wali again, he says that majority of written African literature has been written predominantly in English and French, indicating a direct supremacy of European domination on Africans in all levels of government, education and society. And that all these cannot be discussed outside the context of colonialism, cultural imperialism or a complete spiritual subjugation.

There are other writers who are also in serious support for African languages not only in the realm of literary creativity, but also in other spares of national life (Manang, 2001). Irele (2000), who calls for the originality of African literature, for example, states clearly that it is only a literature written in the continent's indigenous languages that could be rightly be defined as African literature. Towa (1985), on his part, suggests for the development and the use of indigenous African languages. According to the source, the exclusive use of the foreign languages in government and politics would drastically hampers the progress of the poor Africans who do not have the opportunity to master the so-called official languages. And that they would be separated from their leaders in the society. In an attempt to discuss the challenges faced by the African translators, Nama (1989) points to the various limitations that could exist when the translators use of foreign language: there is usually a loss of cultural betrayal in conveying the experiences of a particular society, say African, for instance, in the oppressor's tongue.

According to Ruhumbika (1992, pp. 73-4), the imposed colonial languages would continue to remain foreign even for those African writers who claim interest over them. His warning indicatesthat a new African society would remain illusion provided that African writers continue to write in the languages of former colonial writers. And Kunene (1992, p. 32) declares that African writers writing in English or any other European languages cannot be said to be African true representatives since they speak from the perspective of the imposing colonial tongue.

\section{Chinua Achebe and Other Writers for Foreign Languages}

While Ngugi wa Thiongo's and other critics do not accept the fact that a literature, written in a European language, to be termed or classified as "African literature", the relativists, led by Chinua Achebe, are seriously against their view. These writers argue that any language, whether an indigenous native language or a foreign language that could be well mastered, should equally be used effectively, in creative manner, by African writers in writing African literature. They therefore, oppose the idea that only African languages can be used to addressing African literature. To them, any language could be used to portray African reality, behaviour, experience as well as life style; and as such, literature written in foreign languages can also be classified as African literature. In their view, for example,the only possible way African people could fight against neo-colonial forces, imperialism and subjugation by the colonisers is to write in such a language(s) that the colonisers will understand: that is, the foreign languages. This set of critics believes, however, that English, French, Arabic and Portuguese have come to rescue Africans who do not have a common language, and that there is need to accept the unsolicited gift with gratitude.

For Mphalele (1997), who reacted specifically against Wali and Ngugi's claim, argues that in fighting against neo-colonialism, creative African writers cannot wait until one or two African languages are fully developed if they would meet the need of current contemporary thought: “...creative impulse cannot wait for such developments before it expresses itself. So we write in English, French, and Portuguese, which we know and have mastered" (pp. 337-8). His argument illustrates the fact that a writer can be reliable and valid even when he is writing in a foreign tongue. 
That is, the colonial languages have become common languages with which to present a nationalist front against white oppressors because they provide a sense of unity among Africans, especially in their struggle against colonialism. And that whatever stops African writers from writing in the imposed colonial language(s) and/or foreign tongue(s), such would drastically endanger the progress and development of African literature. The literary sphere, as Mphalele concludes, is that a writer must have the liberty to choose the medium that suits him best, although maintaining that such colonial languages must be deviated and Africanised, but which would still be in a full communion with its ancestral home so as to suit its new African surrounding. This is, of course, why Moore (1997, p. 339) argues that in fighting against colonialism and imperialism, it is not wrong for African writers to speak or communicate to his people or the colonisers in a language(s) in which they understand. To him, a real writer would fight his way to express himself in a language that gives him a hearing and a living.

In his contribution to the debate, Chinua Achebe, an African literary giant, claims that African writers would continue to write in English or French or any other foreign languageno matter the consequences that would bring to the audience of their work. Although he accepts the fact that it is only those educated elite Africans that would benefit more if African writers continue to write in foreign languages, yet he argues that writing in English or French, among other colonial languages, is a practice of present day Africa which is a possible way of unifying Africans who are already of different linguistic backgrounds. Achebe (1975a) believes that a true national literature that would meet his wider audience would only be possible through English. He maintains that his option of writing in English is not actually a sign of submission or a sign of abandoning his native language (Igbo)because it is not right for anyone to abandon his L1, but that he has no choice. And writing in English is a possible way of solving the problem encountered by Africans:

It is right that a man should abandon his mother tongue for someone else's? It looks like a dreadful betrayal and produces a guilty feeling. But for me there is no other choice. I have been given the language and I intend to use it. (p. 62)

Demonstrating his creativity in both his fictional and non-fictional writings, set in all African oral heritage and tradition like proverbs, riddles and myths, among others, Achebe bends the English expression to suit his L1, suggesting that such literature must seek to articulate a new African identity through Africanisation. Achebe's (1975b) opinion is that a writer must write in a language thathe (the writer) and the readers understand: "no man can understand whose language he does not speak" (p. 48). And that English has offered a great advantage to produce a literature that conveys his peculiar experience. His earlier novels, Things fall apart and Arrow of God, for instance, show exactly how Achebe has Africanised the English language. As such, he argues that there is nothing wrong in writing in English. In his words, Achebe agrees that although Africans can write and speak English very well, they cannot do it effectively compared to the native speakers of English. He cites Tutuola (1952), who in his Palm-wine drinkard, written based on Yoruba mythology,could not express himself adequately in English even though he (Tutuola) is writing in English. In his response to the novel, Achebe declares that the use of the English is as a result of the audience he (Tutuola) was talking to, and that any grammatical error can be made by a non-native speaker.

Achebe argues that even though colonisation has destroyed so many things in Africa, it has nevertheless provided other advantages: first, it has provided big political unit to Africa, replacing the smaller ones earlier in existence. Second, it is the colonisation that has possibly provided African people with a language with which to talk to one another: "if it failed to give them a song, it at last gave them a tongue"(1975a, p. 57). He defines African literature as the sum total of all the national and ethnic literature of Africa which any language can serve, and to him, especially in Nigerian environment where there are several ethnic groups, writing in English is the possible solution "...for good or ill, that language is English" (1975a, p. 58). Although he instructs that the English language should not be used in such a way that its value as a medium of international exchange will not be lost, yet Achebe (1975a) maintains that such English (a new English) would be fashioned and altered in a way that it would carry the weight of African experience and suit its surrounding:

The price a whole language must be prepared to pay submission to many kinds of use. The African writer should not aim to use English in a way that its value as a medium of international exchange will be lost. He should aim at fashioning a form of English that is at once universal and able to carry his peculiar experience. (p. 61)

Achebe's reason is that Nigeria is a multilingual nation with several ethnic groups and languages. In such a diverse nation, it is only the languages introduced by the colonisers that would serve as a common language: English becomes the only medium of expression. He accepts the fact that English is a free language given to him, not 
imposed; it is a worldwide language, serving as an official language in his country. To him, limiting one to such official Nigerian languages like Hausa, Igbo and Yoruba, means that the writer is communicating to a smaller group of people only, not to a larger Nigerians, and that there is no possibility of an adult to acquire all the three major indigenous languages at a time. Achebe questions whether Swahili, Hausa, Igbo, Yoruba and Afrikaner, among the widely spoken African languages, could represent African lingua franca. If the response is yes, he asks whether those languages are spoken in all parts of the African countries. He concludes that writing in vernacular languages would restrict the number of readers, pointing out that many Africans are acquiring English or French as their L1 in the first instance. And therefore, African writers would continue to write inEnglish or French. Achebe illustrates instances where he is unable to read books given to him by a Swahili poet, Shabaan Robert, because he does not know how to speak Swahili (Achebe, 1975a). He suggests that if African literature cannot be written in the imposed European languages, its goal cannot be achieved.

Wiwa (1992), who is also in support of the forign languages, argues that it is only the language of the colonisers, English language precisely, that he can share his own experience with his people who are mostly diverse. Although it is a language of the colonisers, he claims that English is the only common language through which his people can establish contact and understand each other. To him, writing in English enables a writer to reach a wider relationship, not only in his home country, but also internationally since English is spoken nearly all over the globe. Wiwa challenges other writers who are seriously against colonial languages: he claims that writers have choice, and that if one writes in English or any other colonial language does not stop him from writing in his L1. To him, it is English language that has made it possible for him to be exposed to other linguistic groups; otherwise, his L1 only would not have made it possible: "I remain a consumer or practitioner of African-literature in English" (p. 157).

Others who counter Ngugi and Wali's argument of authencity of African literature are Amos Tutuola, Wole Soyinka, Guy Bukler, Buchi Emecheta, Leopold Senglor, Aireme Cesaire and Moradewun Adejunmobi, among others. They all agree that the imposed colonial languages have become lingua franca for Africans who do not have a common language. To them, while they are writing in foreign languages, they would first approximateand deconstruct them. After that, they reconstruct and transform the said colonial languages in a new literary form to suit the need of African cultural heritage and experience. In their conclusion, even though African writers write in Portuguese, French, Arabic or English language, they would never use them the way the British do: the languages must be restructured in such a way that would address the need of Africans.

This group claims, however, that they cannot use the English language the way the British use it, as such it would be used in such a way to match their purpose. They argue that the temptation one might face in writing in indigenous African languages is lack of communication because many Africans grew up as children in their different L1, but received their higher education in colonial languages. The education received comprises literature and philosophy, and that the only possible way is to write in European or colonial languages because they would reach a wider audience. Their opinion therefore, is that African literature should be seen in a pan-African viewpoint, addressing the need of Africans whether written in indigenous African languages or in foreign languages.

Adejunmobi (1999), who heavily criticises African writers writing in indigenous languages, argues that their works are not capable of fighting back to the oppressors or are not involved in the fight against colonialism. Rather, they only reflect the immediate community's need. According to his reasoning, only the writers who write in colonial languages have come together to provide a "common political and cultural agenda" (p. 589), and that if African writers are intended to address the world as a whole, they must adopt the European or foreign languages, even though they are the languages of the colonisers. Adejunmobi concludes that the "debate itself" over which language would be suitable for African literature would only continue in European languages and not in the native languages. And such complications would eventually make one chooses the colonisers' languages, as against native African languages since they enjoy nation-wide currency.

\section{Standpoints}

Based on the arguments, it is obvious that while Ngugi and other critics' argument are patriotic to Africa since language is power, but it is important to note that their opinion might not fit to solve a practical problem. It can never be argued that Ngugi himself, for example, has widely written in English; most of his works written in Gikuyu have also been translated into English for a wider audience. It would therefore, not necessary and natural for him to stop other African creative writers from writing in English or any other European languages. For Ngugi to conclude that a literature written in a European language other than an African language does not qualify to be African literature, proves the fact that most of his works written in English are not also qualified to be classified as African literature, whereas they are. Like Achebe and other critics, this paper is in the position that any language should be used in 
writing African literature provided that such literature portrays the lifestyles and experiences of Africans. Also any literature written in any of the African languages but which does not address the immediate need of Africans should not also be classified as an African literature: the issue of language should not be necessary in defining African literature.

First, the reason is that, at this stage, writing in indigenous African languages is only to a little audience. Even if one or two indigenous African languages are to be standardised, yet it would really not solve the problem. For instance, if Swahili and Yoruba, which are among the widely spoken African languages, are to be standardised and used as common African languages, the problem would not still be solved because those languages would still serve as a second or foreign languages to some other Africans. It is possible that not everyone would have access to those languages if they are standardised; therefore, they would also perform the same function as those of the colonial languages. Second, these standardised languages would also be limited to a smaller audience than a wider one.

The primary purpose of literature is to inform, entertain and educate (Ukam, 2008; Mokaya, n.d.); if these functions are taken away, then literature seizes to be a composite art. The audience no longer understand the intended massage. English and other colonial languages have come and stayed in Africa; African writers must continue to write with them since they are lingua franca in the mix of multiple African languages: one linguistic group is unable to understand the language of another group. In Nigeria, particularly the people of Erei (a language in Biase Local Government Area of Cross River State),for example, are taught, right from birth how to read and write the English alphabet (A, B, C and D) and the numerals (1, 2, 3 and 4) not in their L1 but in English. The L1 is classified as a vernacular language in a formal environment. It is only English language that is used as an official language and everyone must be trained in that direction if he/she is to communicate with other linguistic background different from his/hers. And most importantly, if translation is to be the only possible option, as suggested by Ngugi, the issue of authenticity might not also be achieved. This is because when one translates, the original meaning is missing and the exact message might not be delivered as supposed.

English and other colonial languages in Africa are like English in America and English in Switzerland, and the same language is used differently in these environments. The colonial languages in Africa need to be used, applied and adopted to perform a diversified function which our indigenous languages have not done since they are yet to be fully standardised or met a wider audience. African literature should therefore, be presented in such a way that would reflect African culture as claimed by Achebe and other creative African writers and critics.

\section{Conclusion}

In this paper, we have discussed two arguments through which a true African literature could be written: those for the imposed colonial languages and others for the indigenous native African languages. It can never be argued that during the colonial period, the term "language" became the primary medium where hierarchical structures of power were exercised. Some postcolonial writers like Ngugi, for instance, have continuously suggested for a return in writing in indigenous languages, urging African writers to constantly write in indigenous African languages if there should be authenticity in African literature. Wali, for example, has expressed dissatisfaction with African literature written in European languages, calling such literary expression as a doom to pursuing a dead end and frustration since it lacks authenticity. And to Ngugi, African literature written in any other language other than indigenous languages is decolonising the mind, and that those writing in European languages are enriching the mainstream of European literary tradition. He sees language as the enabling condition of human consciousness: a practical way of rejecting imperial imposition by the colonists.

It is true that during the colonial period, the colonial languages have been imposed to all official usages, condemning the indigenous languages as impurity, lagging phonetic, morphological and syntactic features. Yet, it can never be argued that it the same languages which most African writers areadopting to expressing their African experiences, cultures and traditions. The truth is that many Africans grew up as children in their L1 but received their higher education in one of the colonial languages: Africans can never do without the foreign languages whether freely given or imposed.Some writers, however, have attempted to blend both native and foreign languages just to reach both the native and the elite audience. For instance, Atukwe Okei, a Ghanaian writer, has tried, in his poetry, to reach an audience of native Ghanaian speakers and intellectual speakers.

Our assumption has been that not until one or two widely spoken African languages are standardised, taught in schools and spoken by at least 80 per cent of African population, European languages would continue to have a greater influence in writing African literature because they are widely spoken in Africa where many indigenous languages are in existence. And that any literature that portrays African experience and identity, whether written in 
any of the imposed colonial languages - English, French, Arabic and Portuguese - or in indigenous native languages should be treated as an African literature.

\section{Recommendations}

1. To avoid language debate among African writers and critics, Africans should agree on one or two languages to be made official, serving as common languages. When this is done, language debate would be resolved.

2. One or two widely spoken African languages should be standardised and adopted as a medium of instruction in all the African schools until majority would have access to those languages. If that is done, and especially used in writing African literature, it will help to define the real identity of African literature. Such languages would serve as central identity, promoting Africans at the international level.

3. While waiting for one or two common African languages to be adopted and standardised, African literature should be written in both foreign and native languages provided that such literature depicts African experiences and peculiarities.

\section{References}

Achebe, C. (1975a). The African writer and the English language. Inmorning yet on creation day. London: Heinemann, 55-62.

Achebe, C. (1975b). Where angels fear to tread. Inmorning yet on creation day. London: Heinemann, 46-48.

Adejunmobi, M. (1999). Routes: Language and the identity of African literature. The Journal of Modern African Studies, 37, 4581-4596.https://doi.org/10.1017/S0022278X99003146

Eme, C. \& Mbagwu, D. U. (2011). African language and African literature. Unizik Journal of Arts and Humanities, 12(1), 114-127. https://doi.org/10.4314/ujah.v12i1.7

Irele, A. (2000). Second language literature: An African perspective. In F. Christiane (Ed.). Anglophonia: French Journal of English Studies, 7-22.

Kunene, M. (1992). Problems in African literature. Research in African Literature, 23(1), 27-44.

Menang, T. (2001). Which language(s) for African literature: A reappraisal? Yaounde. Retrieved from www.inst.at>trans>menang 11

Mokaya, N. (n.d.). The language debate in African literature. Retrieved from www.academia.edu/8015888/THE_LANGUAGE_DEBATE_IN_AFRICAN_LITERATURE

Moore, G. (1997). Polemics: The dead end of African literature. Selections from Transition, 11, 335-341.

Mphahlele, E. (1997). Polemics: The dead end of African literature. Selections from Transition, 11, 335-341.

Nema, C. (1989). The African translator and the language question: Theoretical, practical and nationalistic considerations. In Epasa Moto, 1(1). Buea University Centre.

Ngugi, W. T. (1972). Homecoming: Towards national culture. London: HEB.

Ngugi, W. T. (1986). Decolonising the mind: The politics of language in African literature. Nairobi: James Currey.

Ngugi, W. T. (1990). In write in Gikuyu. In The Courier, op. cit.

Ruhumbika, G. (1992). The African-language policy of development: African national languages. Research in African Literature, 23(1), 73-82.

Towa, M. (1985). Le concept d'identite, in identite culturelle Camerounaise, op. cit.

Tutuola, A. (1952). Palmwine drinkard. London: Faber and Faber.

Ukam, E. I. (2008). The thematic relevance of the folk tradition in Achebe's Arrow of God and Ngugi's Matigari. B.A. Project, Ebonyi State University, Abakaliki.

Wali, O. (1963). The dead end of African literature.Transition, 10, 13-15.https://doi.org/10.2307/2934441

Wiwa, K. S. (1992). The language of African literature: A writer's testimony. Research in African Literatures, 23(1), 153-157. 